\title{
IN MEMORIAM: ELIAS DOLIANITI (1911-1985)
}

Nascido na cidade do Rio de Janeiro, a 26 de janeiro de 1911, filho de Demétrio Elias Dolianiti e Presciliana de Araujo Dolianiti, trazia no sangue a sabedoria e a tradição da milenar cultura grega. Faleceu a 30 de julho de 1985 , aos 74 anos de idade, na cidade que o viu nascer, carinhosamente assistido e confortado por sua esposa Dirce Ribeiro do Valle Dolianiti e sua filha Maria Helena Dolianiti, rodeado pelos inúmeros amigos, querido e respeitado por seus colegas paleontólogos no Brasil e no exterior.

Entrou para o Departamento Nacional da Produção Mineral (DNPM), antigo Serviço Geológico e Mineralógico do Brasil, a 1 \% de dezembro de 1933, como auxiliar técnico da Seção de Petrografia da Divisão de Geologia e Mineralogia (D.G.M.).

Promovido, meritoriamente, a Naturalista do DNPM em 1940, acabou transferindo-se para a Seção de Paleontologia da mesma Divisão, onde teve oportunidade de realizar sua primeira viagem de cunho paleontológico, a 3 de setembro de 1941, para a Chapada Santa, no Acre, onde coletou inúmeros fósseis. Nesta mesma época foi assistente de seu colega e grande amigo, o eminente paleontólogo Prof. Llewellyn Ivor Price.

Em 1944 viajou para a região carbonífera do Estado de Santa Catarina, onde coletou cerca de 3.000 exemplares fósseis da flora de Glossopteris.

No período de 1946 a 1950 , estudou e preparou restos vegetais da bacia terciária do Fonseca, em Minas Gerais, tendo publicado o resultado de seus estudos nos Anais da Academia Brasileira de Ciências.

Na Faculdade de Filosofia, Ciências e Letras da Universidade do Brasil fez as cadeiras de Geologia e Paleontologia, aprimorando seus conhecimentos em Botânica no Jardim Botânico do Rio de Janeiro, com inúmeros cursos de Botânica Geral e Especializada.

Coletou, no periodo de 1950 a 1956 , inúmeros exemplares de vegetais e répteis fósseis nos Estados do Paraná, Santa Catarina, Rio Grande do Sul e Minas Gerais, tendo ainda, por solicitaçāo do Conselho Nacional de Pesquisas $(\mathrm{CNPq})$, acompanhado o Prof. Richard Kräusel, da Universidade de Frankfurt - Alemanha, em seus trabalhos de campo pela bacia sedimentar do Paraná. Nesta ocasiāo, foi designado pelo então Diretor Geral do DNPM, para assumir a chefia da Seçāo de Paleontologia. Em 1956 foi professor de Paleobotânica no Curso de História Natural do Instituto Brasileiro de Bibliografia e Documentaçăo (IBBD).

Em 1960 foi enquadrađo na carreira de geólogo do quadro técnico do DNPM, tendo dado continuidade às suas pesquisas das floras paleozóicas e mesozóicas brasileiras, orientado bolsistas e participado ativamente de trabalhos de campo, até o ano de 1970.

$\mathrm{Na}$ década de 70 até o início dos anos 80 , dedicou-se exaustivamente ao projeto Bacias Carboníferas do Gondwana do Estado de São Paulo, patrocinado pelo Conselho Nacional de Pesquisas $(\mathrm{CNPq})$, com a colaboraçāo do Prof. José Henrique Millan, do Museu Nacional do Rio de Janeiro. Neste mesmo período foi consultor técnico do Projeto RADAMBRASIL, para assuntos relacionados à Paleobotânica.

Sócio da Sociedade Brasileira de Geologia, sócio fundador da Sociedade Brasileira de Paleontologia e da Sociedade Botannica do Brasil, membro do International Bureau of Plant Taxonomy, participou de inúmeros congressos, simpósios e reuniōes científicas nacionais e internacionais, além de cerca de uma dezena de representaçőes oficiais.

Pesquisador do Conselho Nacional de Pesquisas (CNPq), foi eleito, em 1955, membro associado da Academia Brasileira de Ciências, passando a 
membro titular em 18 de janeiro de 1972, por sugestão e apresentação de seu amigo Prof. LI. Price.

A vasta bagagem científica do Prof. Elias Dolianiti reflete um profundo conhecimento da Paleobotânica brasileira, além de uma ampla visão de conjunto que vai desde os árduos trabalhos de campo até às excelentes pesquisas em laboratório. Seu espírito de colaboração era conhecido por todos aqueles que pesquisando nos campos da Geologia e da Paleontologia, recorriam aos seus conhecimentos quando deles necessitavam.

Dedicou a sua vida aos estudos da Paleobotânica brasileira e, apesar dos percalços e das dificuldades da época, publicou mais de 3 dezenas de trabalhos científicos versando sobre plantas fósseis das mais diferentes bacias sedimentares brasileiras, todos eles conhecidos e respeitados por especialistas no assunto.

A segurança, clareza e acuidade demonstrada em seus trabalhos trouxeram-lhe o merecido reconhecimento nacional e internacional, como autoridade em assunto da Flora Gondwânica que tanto o destacou no panorama da geologia do Hemisfério Austral.

12 de dezembro de 1985

Norma Maria da C. Cruz

CPRM, Rio de Janeiro, RJ 